\title{
ALGUNS FIÉIS DA IGREJA UNIVERSAL DO REINO DE DEUS
}

Diana Lima

\begin{abstract}
Muitas causas influíram para que eu viesse a beber; mas, de todas elas, foi um sentimento ou pressentimento, um medo, sem razão nem explicação, de uma catástrofe doméstica sempre presente. Adivinhava a morte de meu pai e eu sem dinheiro para enterrá-lo; previa moléstias com tratamento caro e eu sem recursos; amedrontava-me com uma demissão e eu sem fortes conhecimentos que me arranjassem colocação condigna com a minha instrução; e eu me aborrecia e procurava distrair-me, ficar na cidade, avançar pela noite adentro, e assim conheci o chopp, o whisky, as noitadas, amanhecendo na casa deste ou daquele.
\end{abstract}

Lima Barreto, O cemitério dos vivos.

\section{Introdução}

Dados dos Censos Demográficos, produzidos pelo IBGE até 2000, mostram que no Brasil a vida religiosa está em transformação: em 1940, havia 95,2\% de católicos; 2,6\% de evangélicos; em 1950, 93,7\% de católicos e 3,4\% de evangélicos; em 1960, 93,1\% de católicos e 4,0\% de evangélicos; em 1970, 91,1\% de católicos e 5,8\% de evangélicos. A partir de 1980, essa proporção se altera de forma significativa; neste mesmo ano, havia 89,2\% de católicos e 6,6\% de evangélicos; em 1991, 83,3\% de católicos e 9,0\% de evangélicos; em 2000, 73,8\% de católicos e 15,4\% de evangélicos.

Para os pesquisadores da área, estes números não são novidade. O dinamismo que caracteriza a paisagem religiosa brasileira nas últimas décadas tem sido objeto de atenta reflexão. E também não deve ser nova a informação de que, dentro desse intenso panorama, a Igreja Universal do Reino de Deus (IURD), fundada no Rio de Janeiro, destaca-se em razão de sua rápida expansão. ${ }^{1}$ Se retorno a ela é porque acredito que a elucidação da conversão a essa denominação pentecostal, pregadora da teologia da 
prosperidade, pode informar a compreensão de sentidos - extraídos do imaginário da economia — ordenadores da vida social brasileira dos últimos 15 anos. A aposta no rendimento da visita à religião se deve à ideia conhecida de que as esferas da vida não são separadas, como podem ter querido parecer na modernidade (Foucault 1966; Dumont 1977; Taylor 2007). Desde 2005, com vistas a ampliar a reflexão sobre os significados do êxito material, dos caminhos para a sua conquista e dos seus usos, tenho me concentrado nos fiéis da teologia da prosperidade. Quero saber como são incorporados entre sujeitos sociais oriundos dos setores mais pobres do Brasil urbano os princípios da cosmológica neoliberal endossados pela política econômica brasileira desde a década de 1990.

No sistema cosmológico da Igreja Universal do Reino de Deus, a "plenitude" no mundo é um valor central e o dinheiro é coisa sagrada. Segundo sua teologia, por meio da força performativa das palavras (Mafra 2002; Fonseca 2000), o fiel pode neutralizar o suposto Demônio, responsável pelos males que se impõem à vida, e ter acesso a tudo de bom que a existência terrena pode oferecer (saúde perfeita, harmonia conjugal, riqueza material etc.). A relação entre esse cristão e seu deus é contratual e se mantém nos termos da obrigação recíproca: para receber a graça divina de modo a ser capaz de modificar seu destino no mundo, ele deve "viver de acordo com a fé", entregar regularmente o dízimo, fazer suas ofertas, e "tomar uma atitude".

Essa denominação pentecostal que em seus cultos diários elogia a abundância neste mundo foi, e eventualmente ainda é, alvo de duras críticas por parte da mídia ${ }^{2}$ e da população em geral. Os megaeventos de cura, organizados no espaço público, com música intensa, fervor corporal e circulação de dinheiro, bem como suas pretensões políticas, ${ }^{3}{ }^{\text {impressio- }}$ naram diferentes instâncias da sociedade naquele momento e desde então. Como mostram Giumbelli (2001:87-120) e Mariz (1995:37-52), no discurso erudito - religioso e científico - muitas vezes a Igreja Universal do Reino de Deus é descrita como uma agência de exploração financeira dos pobres ou como uma instituição oportunista e charlatã, demasiado condescendente na exigência de observância das tradições para ser seriamente considerada uma igreja cristã.

Ainda assim, a despeito da amplitude e da profundidade das acusações que sobre ela recaem, a Igreja Universal tem espaço cada vez maior nesta que já foi considerada uma "nação católica" (Teixeira \& Menezes 2006; Birman \& Leite 2000; Sanchis 2001). Ela não apenas cresce em número de fiéis, figurando entre as maiores denominações pentecostais no Brasil apesar de sua juventude, como tem papel importante na consolidação ampla de alguns aspectos religiosos a vicejarem desde a década de 1990 entre os setores po- 
pulares da sociedade: hostilidade à idolatria católica; combate ao Demônio que, no seu entender, maldisfarçadamente se manifesta através de cultos afro-brasileiros; exigência de exclusividade no pertencimento religioso.

Em outro momento (Lima 2007a), argumentei contra uma visão presente na literatura sobre religião, segundo a qual o apelo da igreja para os pobres urbanos brasileiros reside na promessa (supostamente falsa) de prosperidade que ela promove através de uma vigorosa estratégia proselitista. Esta hipótese, além de tornar implícita a estranha distinção entre promessas religiosas falsas e verdadeiras, é insuficiente para explicar por que essa denominação pentecostal, professora da teologia da prosperidade desde o início, em 1977, torna-se atraente a ponto de ampliar o número de fiéis em $25 \%$ a cada ano somente nos anos 1990. Atribuindo a devida relevância às circunstâncias nas quais se dá esse fenômeno, verifica-se que a expansão da igreja aconteceu precisamente quando os símbolos por ela articulados para formular sua mensagem cosmológica — e a própria mensagem — encontram ressonância no sistema simbólico que vem dar sentido à experiência social brasileira mais geral.

Como já coloquei antes, no contexto social em que a IURD se instala, a pobreza sempre foi uma fonte de dificuldades. Contudo, até aquele momento, não passava pela cabeça dos cristãos a possibilidade (e o desejo) de intervir individualmente no plano divino para a humanidade. Em outras palavras, os índices de penetração da igreja durante a década de 1980 sugerem que a figura do "empresário cristão", por ela estimulada e defendida (e por muitos atacada), ainda não tinha alcançado a mesma legitimidade na imaginação moral da sociedade brasileira - e, portanto, o mesmo apelo religioso entre os pobres - que atingiu na última década do século XX. Foi somente então, quando o vocabulário do mercado se alastrou na vida coletiva brasileira, nomeando também as relações travadas fora da e alheias à esfera direta da economia, que a ideia de um "empresário" atuando em "sociedade com Deus" para ser "competitivo" e "vencer a concorrência" tornou-se admissível no universo semântico pentecostal.

Com o objetivo de refletir sobre o carisma da mensagem individualista da teologia da prosperidade (e sobre o valor positivo que esta teologia atribui às coisas do mundo), pensando sobre os processos de racionalização que operam na adesão à sua vertente do cristianismo (Hefner 1993:3-38), volto agora a me deter na trajetória de vida de uma rede masculina de fiéis da Igreja Universal do Reino de Deus. Trata-se de cerca de 20 homens com idades entre 18 e 45 anos, em situação civil variada, residentes em favelas e ladeiras situadas nos limites entre a zona sul e o Centro do Rio de Janeiro. ${ }^{4}$ Para isso, examinarei os elementos dispostos à subjetivação masculina no 
contexto de criminalidade violenta que ora se impõe no Brasil contemporâneo (cf. Machado et alli 2008), acrescentando-se à histórica questão da pobreza, tais como aparecem para os meus informantes. Acredito que em suas estratégias (são estratégias privadas e individuais) para o enfrentamento dos dilemas que se lhes colocam e na urgência com que entre eles se impõem os desafios econômicos reside rico conjunto de indícios para a antropologia da economia.

A discussão sobre a subjetividade masculina foi ensejada pelo material obtido entre os finais de 2005 e 2008, por meio de observação participante em um templo da igreja localizado no Largo do Machado e de longas conversas com alguns poucos de seus frequentadores, ocorridas: 1. na própria igreja; 2. em ocasiões de sua vida social fora da igreja; e 3. mais esporadicamente, nos locais de trabalho de dois informantes. Ela reivindica o reinvestimento em questões de longa duração da história do trabalho no Brasil, uma vez que, em todos os casos, a vida dos informantes e a de suas famílias, há pelo menos duas gerações, ${ }^{5}$ transcorreu nos espaços sociais onde estão as chamadas "classes trabalhadoras urbanas". Alguns desses pentecostais já nasceram no próprio Rio de Janeiro, outros chegaram durante a infância, trazidos pela família, que buscava na cidade um lugar ascendente.

Meu pai tinha uma loja, era uma loja pequena, mas dava... loja de material de construção, no Norte, e a gente não vivia tão mal. Nós viemos pro Rio depois que meu pai morreu, eu era moleque... A minha tia já morava aqui... a minha mãe... não deu lá no Norte, não dava pra sustentar os filhos... ela pensou que ia ser mais fácil aqui, ia ter mais oportunidade aqui... pros filhos (Nilton, 34 anos, casado e pai de duas crianças pequenas).

É aquela coisa: a minha mãe sempre trabalhou em casa de família. Às vezes é que ela vinha em casa. Meu pai, desde pequeno, meu pai nunca tava. Tá sempre no álcool, até hoje. Tava sempre aquela briga em casa. Aí não teve ninguém pra dar uma criação para a gente... Resultado da questão... é o que todo mundo fala, tá entendendo?, a gente andou tudo solto no morro... Eu, todo tempo no tráfico. Eu admirava muito o Ceará. Olhava ele saindo do morro de manhã arrumado, e queria ter coragem pra sair, pra largar o tráfico. Mas eu não tava preparado. Esse trabalho que a gente faz com os jovens é muito importante, a senhora não tem ideia. É aquilo, se a gente quer que as coisas mudem, não pode ficar parado. Eu faço esse trabalho agora que é a minha vez de dar uma oportunidade... um jovem... de sair dessa vida, entende? O Ceará... então agora é a minha vez. Muitas vezes a gente vê famílias sofrendo, tudo destruído, a mãe que não fala com filho, e não sabe por onde começar. A gente leva uma luz. A gente convida, 
a pessoa vem e vê que não precisa ser daquele jeito. Aí vem mãe, vem pai, vem irmão, até vir o irmão mesmo que tá na droga (Netinho, 19 anos, solteiro).

Meu pai aprontava demais. O que ele fazia? Não tinha profissão fixa, não. Às vezes ganhava, às vezes... Uma vez a gente já tinha dado ele morto... aí ele aparecia lá em casa (Edvaldo, 27 anos, casado).

\section{A modernização do Brasil: o processo da desigualdade}

No Brasil, a transição do regime senhorial para a ordem moderna aconteceu de forma lenta, social, cultural e politicamente conservadora (Faoro 1975; Holanda 1971). Aqui, o fim da escravidão e a proclamação da República não foram induzidos pelos ares libertários que se disseminaram pelo Ocidente no século XIX (Carvalho 1987). Muito ao contrário, o longo passado escravagista e a persistência do patriarcalismo rural constituíram represas estruturais importantes à formação de uma sociedade disposta ao desenvolvimento econômico e à mobilidade social universal (Fernandes 2006). E mais ainda, sem o favorecimento administrativo da modernização econômica e de uma reforma social que pudesse absorver trabalhadores formalmente libertos, a praça de mão de obra livre no Brasil constituiu-se tendo como pano de fundo uma atmosfera de profunda degradação simbólica do trabalho manual.

Com a abolição da escravatura, ex-cativos sem propriedade, sem preparo ocupacional sistemático, com habilidades mais ou menos incertas e aleatórias ou sem habilidade alguma (Kowaric 1987; Prado 2005) juntaram-se ao grande contingente campesino de "agregados", "sitiantes", "moradores" e "camaradas" (Franco 1976) e aos "vadios" das cidades que existiam nas beiras da sociedade já desde os tempos do Império. Esses personagens formavam um conjunto de figuras dependentes de relações pessoais de interesses e favores, a quem restavam as tarefas árduas ou as comissões arriscadas. Eram homens "disponíveis", porém considerados "imprestáveis" à dinamização do sistema econômico industrial, e compunham uma vasta oferta de mão de obra para os trabalhos ocasionais que ninguém se dispunha a desempenhar.

A percepção negativa acerca do homem livre nacional, identificado à preguiça e à desonestidade, ao lado dos argumentos científicos então hegemônicos, justificou políticas de incentivo à imigração em larga escala de europeus pobres, sobretudo a partir de 1870. Buscava-se com essas medidas de abertura à força laboral estrangeira solucionar uma suposta "crise de braços" e "branquear" a sociedade brasileira para o seu ingresso no "mundo civilizado". Este projeto de melhoramento da sociedade, re- 
pousado sobre a concepção de que a introdução do elemento estrangeiro naturalmente promoveria transformações positivas na gente brasileira, não envolveu providências legais, educacionais, sanitárias e habitacionais para a acolhida e a incorporação dessa população trabalhadora. O certo é que até o final da década de 1920 a "questão social" jamais havia sido posta na agenda do Estado, insensível ao quadro abrangente de precariedade e miséria. Segundo Fausto (1977) é apenas nessa época, em torno dos anos 1920, com a intensificação das mobilizações operárias, que a legitimidade da categoria trabalhadora e a preocupação oficial com sua integração à ordem social ganham alguma expressão. Conteúdos programáticos mais precisos e o reconhecimento gradual da necessidade de uma legislação específica para o trabalho, até então instável, desregulado e muito mal remunerado, começam a se desenhar na entrada da década de 1930.

Nesse momento, o Estado de Getúlio Vargas, comprometido com a ampliação e a consolidação da indústria no Brasil, sistematiza a legislação trabalhista e ordena assim algo que, nos termos empregados para a compreensão das sociedades modernas, pode ser chamado de um mercado de trabalho (Weinstein 1996). Deste ambiente "desenvolvimentista" surge uma série de novas ocupações, em tese, pontos de partida para a democratização do acesso a oportunidades de ascensão social individual, trazendo desta vez para a região Sudeste um importante contingente de migrantes nordestinos (Fontes 2008). ${ }^{6}$ Não obstante, embora entre 1940 e 1980 o Brasil tenha modificado completamente sua distribuição demográfica e conseguido multiplicar por 15 o seu PIB, alcançando, em 1980, a posição de oitava economia do mundo, o crescimento da riqueza brasileira aconteceu de maneira altamente concentrada.

No último decênio do século XX, em função do processo de urbanização iniciado nos anos 1950 e aprofundado na década de 1970, menos de 20\% da população brasileira encontrava-se no campo. Mas é preciso não esquecer que essa modernização, geradora dos altos índices de crescimento, abriu, ela mesma, muitos postos de trabalho urbano desqualificado, como na construção civil, por exemplo. Essas oportunidades atraíram a população rural em larga escala para a cidade, sobretudo da região Nordeste para a Sudeste. Essa gente, porém, nunca encontrou uma acolhida sólida na cidade, e a estagnação econômica, vivida a partir do início da década de 1980, foi com ela impiedosa. A precarização da habitação popular, das redes públicas de educação e de saúde dirigiu parcelas importantes dessas pessoas e, mais tarde, de seus filhos ao mercado dos pequenos serviços, à informalidade ou à marginalidade.

Mendonça, fiel da igreja desde 1998, me disse em 2006 o que conhece do mercado informal de trabalho braçal: 
Não sei se tu sabe, tu não deve saber que tu trabalha lá na universidade. Mas eu te digo, cara, no Brasil, o camarada que mais trabalha é o que menos ganha. E não é por nada, mas eu sempre achei isso injusto. Pode ver, cara, num transporte, o cara que mais leva é o dono do transporte. Eu já trabalhei. Os ajudantes, quem carrega a carga mesmo, bota, tira, carrega, trabalha mesmo, esse cara, o dia inteiro trabalhando, ganha uma mixaria.

Em outro momento, ao me contar sobre como começou seu "negócio", ele me disse mais: "Esse meu pensamento eu sempre tive. Eu nunca fui acomodado. Eu sempre procurei uma chance, falava com todo mundo, procurava... A igreja ajuda muito a pessoa nesse sentido".

Nos anos 1990, os parâmetros claramente tomados de empréstimo da simbólica mercantil, que vieram presidir a política econômica e social nos últimos anos e frequentar com euforia o jornalismo econômico e o colunismo social (Lima 2007b), talvez tenham alçado o país à condição de economia emergente e consolidado o anseio individualista pela autonomia ocupacional em diferentes estratos sociais. Ainda está por acontecer, contudo, uma revisão mais profunda da estrutura socioeconômica brasileira.

\section{Homens na igreja: pentecostalismo e gênero}

Ao tratarem da redefinição provocada pelo pentecostalismo no feminino, Machado e Mariz (1996) lembram que, em Economia e sociedade, Weber já sublinhava a grande suscetibilidade das mulheres ao cristianismo. Em seu artigo, as autoras não prometem explicar a(s) razão(ões) para a maior presença de mulheres do que de homens nas igrejas pentecostais, porque isto não é uma surpresa: as mulheres são maioria nas demais igrejas cristãs $i^{7}$ o pentecostalismo atrai as pessoas cotidianamente mais afligidas por problemas dolorosos, e entre elas "estão os mais pobres, os negros, os mais velhos, os enfermos, os desempregados e as mulheres". Seu objetivo é analisar o que o pentecostalismo "oferece a essas mulheres e/ou quais são as consequências da adesão a esses grupos religiosos em suas vidas". A Machado e a Mariz interessa a subalternidade das mulheres na relação de gênero, mais do que na hierarquia social.

Em suas próprias palavras:

[E]mbora as mulheres pentecostais mantenham-se distantes dos projetos libertários feministas, a experiência de conversão e sua ênfase na responsabilidade pessoal, tanto pela sua salvação espiritual como pelo sucesso nesse mundo, 
provocam uma redefinição na forma de as mulheres se conceberem enquanto indivíduos, o que tenderia a favorecer o processo de autonomização feminina "solapando" o machismo tradicional (:142).

As autoras dividem em dois blocos a literatura sobre o efeito do pentecostalismo na vida dos latino-americanos mais desfavorecidos. De um lado, estão os trabalhos insistentes no caráter alienante e reforçador da opressão das religiões pentecostais: ao sublinhar a moral cristã e exigir dos fiéis uma vida ascética, o pentecostalismo obscureceria sua consciência crítica acerca da sua condição de classe dominada. Mais recentemente, o caráter de "instrumento de luta de pequeno alcance que ajuda aos oprimidos" tem sido aceito pelos autores e vem criando maior consenso nos trabalhos sobre religião.

No segundo grupo, os estudos indicam que as mulheres de camada popular são mais beneficiadas pela conversão quando acompanhadas por seus parceiros. Porque nesse caso, dizem os pesquisadores, além de operar no fortalecimento da autoestima feminina, o pentecostalismo transforma os homens (Burdick 1993; Brusco 1993; Cucchiari 1990; Machado 1996) com quem elas levam seu dia a dia. Apesar de mais resistentes à moral da contenção sexual e à exigência de maior igualdade no compromisso com a família, uma vez convertidos, eles aproximam-se da vida doméstica e afastam-se do álcool, do adultério etc., além de perceberem o mundo e a si mesmos de maneira mais igualitária. ${ }^{8}$

Embora os poucos números produzidos sobre a membresia da Igreja Universal revelem que ela reproduz e talvez acentue essa proporção entre os gêneros, a minha entrada na igreja, no segundo semestre de 2005, foi mediada por um jovem adulto casado e pai de duas crianças gêmeas, que me apresentou à sua rede de amigos formada por homens cuja idade varia entre 25 e 42 anos. Não teria sido possível circular naquela sociabilidade sem a chancela desse primeiro contato, porque depois de terem sido tantas vezes objeto de ataques, os fiéis e, mais ainda, o clero, não são receptivos a pessoas cuja origem social diversa da sua está evidente de imediato, na aparência. Ademais, assim como em outras religiões, os templos locais da Igreja Universal ${ }^{9}$ reúnem pessoas que se conhecem bem entre si e controlam a presença de estranhos - mesmo que seja para então acolhê-los.

Eu havia me aproximado da igreja porque suspeitava estar em operação ali um mesmo conjunto de valores relativos às esferas do trabalho e do consumo com que me deparara em uma pesquisa concluída em 2004, entre sujeitos sociais da elite econômica do Rio de Janeiro (Lima 2007b; 2008b). Não havia por trás da minha curiosidade sobre os modos como se alastraram 
nas classes trabalhadoras urbanas a forte positivação do "empreendedorismo" e o intenso desejo por bens de consumo nenhum planejamento de gênero. Muito menos havia qualquer raciocínio a priori de tipo funcional, ligando "assuntos econômicos" a "homens", no projeto que permitiu o engate entre os dois momentos da minha investigação sobre o que venho nomeando "ethos emergente". Não fui à Igreja Universal à procura de homens para entender como uma suposta autoevidente relação entre masculinidade e trabalho/dinheiro/consumo pode se apresentar.

Antes, não é infundado atribuir ao acaso a inclinação desta pesquisa para o lado dos homens da IURD. Apesar de ser a expansão do pentecostalismo um fenômeno majoritariamente feminino, foi deles que pude ouvir coisas estimulantes para o enriquecimento do clássico debate sobre a afinidade eletiva entre ética religiosa e disposição econômica, razão do meu interesse inicial de antropóloga da economia por essa igreja em particular. Não é que eles falassem de trabalho e as mulheres falassem de outros assuntos, interessantes para outras reflexões. Isto eventualmente também ocorreu e faz parte do que chamo de material empírico, do interior do qual retiro esta análise. Mas o meu ponto aqui é que o meu trabalho de campo teve sua dinâmica muito ditada pela disponibilidade do meu "embaixador", para tentar uma metáfora da nossa relação, e na maior parte do tempo se deu entre os seus amigos, homens.

Meu primeiro informante, assim como esses amigos, começou a trabalhar muito jovem, interrompendo a escolarização antes de chegar ao ensino médio. Eles circularam no mercado de serviços não-qualificados por muitos anos, atravessando uma sucessão de empregos e subempregos que prescindem de formação e são, aparentemente por isso, muito mal remunerados. Alguns retornaram à escola e completaram os estudos depois da adesão religiosa. ${ }^{10}$ Todos, com exceção de um deles, funcionário do Banco do Brasil, partiram para a iniciativa comercial individual depois da conversão à igreja, durante a década de 1990. A satisfação com esta medida é unânime entre eles. Suas moradias equipadas com eletrônicos, suas crianças em escolas particulares, o acesso familiar à medicina privada e, em alguns casos, as fotografias de viagens em férias me foram apresentados como se atestados da pertinência de seu entusiasmo.

Não me parece impróprio suspeitar que esse sentimento tenha sido de fato o que os motivou a colaborarem comigo, dando-me relatos sobre suas trajetórias e depois me admitindo em seu convívio. Muitas vezes ouvi que me veem como uma alma a ser convertida. "Deus tem muitos caminhos. Tu pensa que tá fazendo pesquisa e ele te bota na igreja. Vai saber". Porém, aconteceu de entre nós a conversa correr solta e Deus, a igreja, a Bíblia etc. 
desaparecerem para que ficássemos falando do que nós, das ciências sociais, chamamos de "a questão social" e de onde eles, das classes trabalhadoras urbanas, entendem que ascenderam "com Deus" para dar "condições" aos filhos, poder "passear" e não ter mais que "aguentar humilhação".

Esses fiéis contavam entre 8 e 12 anos de adesão à igreja quando iniciei a pesquisa. Eles se conheceram no templo do Largo do Machado, onde ocorreu a maior parte das conversões. Vários deles têm a mesma ocupação - são corretores de previdência privada - o que não só remete às ligações em rede, mas faz ver ali a presença da ajuda mútua. Para os desempregados ou mal empregados e para os que desejam deixar o crime para fazer seu "caminho no espírito" há sempre uma chance como principiante no escritório de vendas de um correligionário; para os reincidentes em álcool ou nas drogas - como um deles, com quem outros três passaram muitas noites, ausentando-se da igreja para "orá[-lo]" (sic) e "fortalecer o espírito dele contra o pó" — há sempre uma palavra e, se necessário, um esforço coletivo de "resgate" organizado pelos obreiros da igreja.

Na Igreja Universal do Largo do Machado, na zona sul do Rio de Janeiro, e depois em outros templos pela cidade, as pessoas com quem interagi não eram apenas muito vulneráveis em termos materiais. Até a conversão, muitos cultivavam os hábitos condenados pela moral evangélica e vários tiveram também uma passagem pelo crime em sua biografia, desde pequenos furtos para a compra de "roupas de marca" na adolescência até o tráfico de drogas, e mesmo homicídio.

Contudo, sabe-se que em todos os meios sociais modernos, mesmo nos contextos metropolitanos mais críticos, existem alternativas de vida. Seguindo a lógica desses homens, pode se dizer que elas vão desde, em um extremo, a adesão religiosa - a Igreja Universal é então uma das possibilidades - até o crime, ${ }^{11}$ no outro. Portanto, é evidente que atrelar contexto e destino social numa relação de causalidade simples significa obstruir a reflexão. Para elucidar em sua densidade esses personagens originalmente muito pobres e sem instrução, que se sentem contentes com seu "sucesso na vida" e atribuem à conversão à teologia da prosperidade forte papel nesse processo, parece-me que é para os operadores disponíveis à confecção da identité de soi (Veyne 1987) que se deve olhar. Como se fazem as escolhas em espaços sociais marcados pela frustração? E como conduzem hoje seu destino, muitas décadas depois de termos nos tornado modernos (ou, melhor dizendo, muitas décadas depois de termos sancionado o direito à igualdade de oportunidades de mobilidade social individual), na cidade do Rio de Janeiro, os homens pobres e sem qualificação profissional? 


\section{Masculinidades}

Já está claro para a antropologia que o masculino não é um bloco monolítico (Herzfeld 1985; Almeida 1995; Cornwall \& Lindisfarne 1996; Gutmann 1996; Archetti 2003, 2007). Ainda assim, cabe guardar em mente que:

a masculinidade hegemônica é um modelo cultural ideal que, não sendo atingível por praticamente nenhum homem, exerce sobre todos os homens um efeito controlador, através da incorporação, da ritualização das práticas da sociabilidade quotidiana e de uma discursividade que exclui todo um campo emotivo considerado feminino; e que a masculinidade não é simétrica da feminilidade, na medida em que as duas se relacionam de forma assimétrica, por vezes hierárquica e desigual. A masculinidade é um processo construído, frágil, vigiado, como forma de ascendência social que pretende ser (Almeida 1995:17).

Almeida apreende os sentidos do "ser homem" em uma aldeia em transformação "pós-agrária" da Europa do Sul. Naquela socialidade popular ibérica, a posição na estratificação social, o trabalho, a honra, a força física, a inteligência, a contenção emocional, o papel na família e a virilidade são as noções e as hierarquias que estruturam o sistema classificatório - da produção e da reprodução - partilhado para a construção social dos homens. O processo da masculinidade, segundo o etnógrafo, se dá no espaço social da rua, que abrange o trabalho, o bar, os jogos intragêneros e se opõe ao da casa e ao da igreja, femininos.

O benefício do estudo de Almeida está mais no fato de ter assumido a masculinidade como um fenômeno social, objeto de etnografia, do que na revelação dos valores e do modo como esses valores são arranjados pelos homens e pelas mulheres para a constituição dos gêneros em Pardais. Seu quadro alentejano não traz uma paisagem restrita àquele espaço social. Porém, creio ser, por isso mesmo, fonte de boas pistas para a elucidação das subjetivações masculinas em ambientes culturais ibero-americanos.

No Brasil, a masculinidade pouco foi estudada como um tema em si. Em compensação, a importância da condição de trabalhador para a construção identitária nas camadas populares é frequentemente discutida com profundidade (Borges 1993; Chalhoub 2001; Corrêa 1994; Decca 1987; Duarte 1986 e 1999, Fontes 2008; Franco 1976; Kovaric 1987; Lopes 1978; Rago 1985; Zaluar 1985). As pesquisas mostram como o contraste desta categoria com a de bandido, ${ }^{12}$ que quer "dinheiro fácil" e se dispõe a "botar arma na cintura", é usado com orgulho, quando acionado para a autorreferência, e com respeito, sinal de maior valor moral, quando empregado para qualifi- 
car outrem. O trabalho é percebido de modo positivo, grosso modo, porque assegura a renda necessária à sobrevivência da família - cuja densidade enquanto valor social no Ocidente constitui objeto de intenso e diversificado debate que agora não é tempo de refazer. A emancipação feminina nas camadas populares urbanas e a entrada das mulheres no mercado, sem dúvida, transformaram os papéis de gênero, complexificaram a divisão do trabalho doméstico, puseram em disputa o patriarcalismo, mas tive indícios de que não eliminaram a força simbólica da figura tradicional do provedor sobre os homens. ${ }^{13}$

A oposição em relação ao patrão, que histórica e frequentemente aparece como agente de incompreensão, humilhação e exploração (Duarte 1986 e 1999), e em face do Estado, determinador de um salário mínimo demasiado insuficiente, aflige os trabalhadores e provoca uma visão fortemente negativa do assalariamento. Afora os aborrecimentos advindos das relações laborais, a instabilidade do vínculo e a baixa oferta de boas oportunidades são apontadas pelos pobres como razão para as mudanças constantes de emprego e para o anseio pelo trabalho por conta própria. Muitas vezes, essa transição é feita paulatinamente: ainda empregado, nas poucas horas vagas, o trabalhador, extenuado, faz pequenos serviços que ajudam a complementar sua renda.

A trajetória própria e familiar dos fiéis da Igreja Universal do Largo do Machado com quem convivi é bem coincidente com esta, documentada e problematizada pelas ciências sociais. É assim que para eles a adesão à igreja tornou plausível a possibilidade de realização do desejo difuso, embora histórico, de trabalhar por conta própria, livrando-se da "vidinha de humilhação" e de perspectivas salariais muito restritas. "A solução está na sua mão. Só os bobos deixam passar a oportunidade", dizem na igreja os pastores, e dizem nos dias de evangelização nos morros da cidade os rapazes e as moças do grupo jovem.

Na igreja eles descobriram que "Deus tem uma recomendação para os cristãos". Compreenderam que para alcançar e manter a "abundância" planejada pelo Criador é preciso: estar "limpo", "trabalhar com estratégia", "determinar", seguir participando das atividades da igreja toda semana, mesmo depois de conseguido o que se pediu a Deus, entregar o dízimo com regularidade e fazer ofertas à obra na medida do que se deseja conquistar. "Deus não quer essa miséria para os seus filhos. Isto não está na Bíblia não. Isto é coisa de católico", me explicou, assertivamente, um dos rapazes. "Mas o que é que adianta ficar na igreja? O cara ficar socado na igreja não leva a lugar nenhum, não. O cara tem que se levantar pra correr atrás, tá entendendo? Mas com Deus!", continuou ele, como que para concordar com Duarte (2005:139-176) que a atitude mais abrangente que os sujeitos 
sociais têm em face do mundo é o que os motiva na opção por uma entre as diversas possibilidades de adesão confessional.

Desde a década de 1990, eles ouvem na igreja ${ }^{14}$ a mensagem (tatcheriana? cristã?) sobre as possibilidades de sucesso do "empreendedorismo", o que, segundo dizem, os fortaleceu (Durkheim 1970:303-313) e os preparou para deixarem o seu "empreguinho sem futuro" e, "em sociedade com Deus", partirem para o longamente almejado trabalho autônomo. "Não é que eu não acreditasse, eu queria, mas tinha medo. Eu não tive um pai pra me dar um exemplo".

Ainda que eventualmente se sintam tentados pelas coisas do mundo drogas, bebidas, festas, mulheres - e muitas vezes sejam alvo de deboche por parte de antigos amigos, os homens da Igreja Universal do Reino de Deus recusam veementes as acusações de manipulação e orgulham-se de sua decisão pela participação na obra divina. Não raro evocam a marca masculina da razão para justificar o que afirmam ter sido uma escolha consciente pela conversão a esta instituição, para eles, erroneamente considerada enganadora de pobres e ignorantes. "Quem fala de lavagem cerebral não sabe o que tá falando. É só o sujeito abrir a Bíblia pra ver que tá tudo ali. A igreja não inventa nada, o que o pastor falar, não tem nada inventado, tudo lá é baseado na Bíblia. Agora, tem muita gente que cita a Bíblia, mas que na verdade nunca abriu pra ler o que tá escrito".

\section{De homem para homem}

A muito criticada versão da Igreja Universal para o antigo dilema ocidental do bem e do mal ${ }^{15}$ é a seguinte: Deus é bom e protege seu povo, como se pode verificar em tantas passagens na Bíblia, desde Abraão. Há no mundo, entretanto, um poderoso antagonista de Deus, o Diabo. Ele é o responsável por tudo de ruim que acontece: miséria, conflito conjugal, violência, doenças, drogas, guerras e, inclusive, "moleza". Assim como o Espírito Santo pode se manifestar a qualquer momento entre os cristãos, o Mal também está permanentemente em atividade. O destino da humanidade não está dado e, se alguém não tem Deus consigo, está vulnerável ao trabalho impiedoso do Mal ${ }^{16}$ que aproveitou o encolhimento da aceitação de Jesus entre os homens modernos para se fortalecer e alastrar sua presença no mundo.

Em seus termos, o dízimo, as ofertas, a boa conduta, além do empenho no alcance daquilo que se deseja são a contrapartida do cristão à bondade divina. Ao aderir à Mensagem, o fiel da Universal torna-se um aliado ou, nas palavras da igreja, um sócio de Deus na luta contra o Demônio. Ele coloca sua "fé em ato" e será por isso individualmente privilegiado, recebendo do 
Senhor "a vida plena e feliz"17 a que tem direito no mundo todo aquele que se mostrar um bom filho de Deus. O dinheiro arrecadado de cada cristão é imprescindível também para a manutenção da Obra, porque sustenta a igreja e permite a sua expansão espiritual. Ao espalhar a boa nova do evangelho, a igreja quer salvar milhares de almas e libertar o mundo inteiro do Mal, culpado por todos os pesares da humanidade.

A relação de reciprocidade entre os cristãos da Igreja Universal e Deus admite o paralelo com a tônica do contrato imposto por Jeová ao povo israelita, como querem as lideranças da igreja? Aquela "relação contratual trazia consigo determinados deveres rituais, sacrojurídicos e eticossociais para os contratantes humanos, mas também compromissos claramente definidos do contratante divino, cuja inviolabilidade este se sentia no direito de exigir nas formas indicadas" (Weber 2004:287). Não será do mesmo modo que o fiel da igreja dá a sua parte e assim espera de Deus aquilo que, pobre ou rico, acredita ser seu como cristão? Só os escolhidos conseguem ter a perseverança necessária para cumprir com sua obrigação e assim obter, neste mundo, a sua salvação e a de sua família.

Mas isto não é tudo. Para esses relativamente jovens fiéis, o maior apelo do cristianismo reside no poder transformador do amor mútuo e constante entre a divindade e a humanidade (cf. Veyne 2007). A Igreja Universal enfrenta a "malignidade" (Birman et alli 1997) que ronda as camadas populares brasileiras, há tanto tempo aprisionadas na escassez de oportunidades, reevocando a bondade e o poder infinitos de Deus. Embora este aspecto da sua mensagem não seja lembrado quando essa denominação está em questão, o amor de Deus por seus fiéis e de seus fiéis por Deus é afirmado no templo do Largo do Machado repetidamente nas prédicas, nas melodias e nas letras dos hinos entoados. Copio abaixo, da "Harpa Cristã", um hino que ouvi muitas vezes durante o trabalho de campo:

Hino 004: DEUS VELARÁ POR TI

1

Não desanimes, Deus proverá;

Deus velará por ti;

Sob Suas asas te acolherá;

Deus velará por ti.

Coro

Deus cuidará de ti

No teu viver, no teu sofrer; 
Seu olhar te acompanhará;

Deus velará por ti.

2

Se o coração palpitar de dor,

Deus velará por ti;

Tu já provaste Seu terno amor.

Deus velará por ti.

3

Nos desalentos, nas provações,

Deus velará por ti;

Lembra-te d'Ele nas tentações;

Deus velará por ti.

4

Tudo o que pedes, Ele fará;

Deus velará por ti;

E o que precisas, não negará.

Deus velará por ti.

5

Como estiveres, não temas, vem!

Deus velará por ti;

Ele te entende e te ama bem!

Deus velará por ti.

A ideia do amor divino foi capaz de atrair o primeiro cristão, conformálo a uma regra e, em troca, oferecer à sua existência "um significado eterno no interior de um plano cósmico" (Veyne 2007:37). É ainda hoje capaz de capturar a confiança de homens que apostam na positividade moral do trabalho e, sem Estado e sem estudo, buscam segurança e método para perseguirem o objetivo que definiram para si e para sua família: a prosperidade, no mundo, agora.

A misericórdia infinita de um Deus passionalmente envolvido com o destino da humanidade - digo, com o destino das almas uma por uma, a minha, a sua, e não somente com o destino dos reinos, dos impérios ou da humanidade em geral; um Pai, cuja lei é severa e faz caminhar em linha reta/caminhar direito, mas que, como o deus de Israel, está sempre pronto a perdoar (:42; tradução minha, grifos meus). 


\section{Considerações finais}

No presente artigo refleti sobre conversões de homens de idade entre 18 e 45 à Igreja Universal do Reino de Deus, a partir do material empírico coletado entre integrantes de uma rede de frequentadores de um templo da igreja na zona sul do Rio de Janeiro. Apesar de as mulheres serem indiscutivelmente majoritárias, minha entrada no campo dirigiu-me aos homens da igreja, o que me levou a manter a atenção etnográfica sobre eles. Infelizmente, não há dados quantitativos que permitam um acompanhamento da participação na IURD por gênero. As informações gerais sobre o pentecostalismo referem-se a uma proporção de dois terços de mulheres e um terço de homens nessa população. A minha impressão é a de que essas frações são verdadeiras na igreja que frequentei. Não posso fazer afirmações seguras sobre o quanto esses homens que ouvi são representativos da totalidade dos homens da Igreja Universal e nem mesmo daquele templo em particular. Suponho que sejam, mas não foi isto que me permitiu tomar os sinais reunidos entre eles como subsídio para uma análise dos aspectos envolvidos na adesão a essa igreja professora do direito à prosperidade no mundo. Para mim não há dúvidas de que suas trajetórias, porque exemplares do que é possível no Brasil de hoje, provocam o pensamento.

As informações demográficas situam a membresia dessa denominação pentecostal entre as pessoas originárias dos meios mais pobres e as menos escolarizadas dos centros urbanos do país. A "questão social" é um desafio histórico, mas ainda que a miséria urbana seja muito séria e torne-se mais perturbadora quando se inclui no panorama a dimensão da criminalidade violenta que se impõe com o estabelecimento em escala global do tráfico de drogas, eu recuso a associação imediata entre contexto sócio-histórico e adesão religiosa. Esta medida analítica deve-se a dois fatores: 1. sabe-se que, embora massiva, a adesão religiosa não é a única via nas camadas populares, sobretudo quando se pensa em homens; 2 . nos casos de conversão, as possibilidades religiosas presentes no mundo contemporâneo são diversas entre si. Não é preciso ir longe, basta verificar a diversidade interna ao próprio pentecostalismo.

Desafiada a relação causal entre contexto e destino social, encaminho a argumentação na direção dos processos de subjetivação masculinos, de modo a compreender como se dão as escolhas pela conversão religiosa à Igreja Universal do Reino de Deus especificamente. Encontro boas indicações no conjunto da reflexão sobre masculinidade ibero-americana e nos estudos sobre identificação social nas classes trabalhadoras brasileiras. Justamente, ali verifico que a condição de trabalhador em oposição à de bandido é, 
historicamente, crucial como valor, mais ainda entre os homens. A pesquisa empírica permite perceber que no meio examinado, a despeito da penetração dos significados modernos relativos à igualdade entre os gêneros nos meios populares, o papel de esteio de família não perdeu sua importância simbólica para a realização das subjetividades masculinas.

Indo além, a literatura antropológica sobre o valor do trabalho mostra que a historicamente frustrante relação com o patronato e com o Estado brasileiro faz da possibilidade de "não depender de patrão" um forte anseio entre os pobres. Este sentimento alastra-se e torna-se ainda mais intenso nos últimos tempos. De um lado, as oscilações da economia transformam o desemprego — ou a desocupação em geral, na informalidade também — em um risco mais e mais difícil de contornar; de outro, termos tomados de empréstimo da semântica neoliberal ganham espaço e exposição insistente na mídia audiovisual e impressa na segunda metade da década de 1990, tendo como efeito, entre outros, a consolidação da crença de que, nesta "economia emergente", o "sucesso" é uma questão de empenho "empreendedor" individual (cf. Lima 2008b).

A Igreja Universal do Reino de Deus, em seus serviços religiosos diários, prega que a salvação, sob a forma de prosperidade, chegará no mundo para todo aquele que "aceitar Jesus". Mais do que em outras igrejas pregadoras da teologia da prosperidade, a IURD imprime um tom pedagógico aos seus cultos. Nesta igreja os fiéis pedem a "vitória", cantam por ela, gritam por ela, pagam o dízimo por ela e aprendem sobre como alcançá-la com o clero, que lê e comenta toda semana casos simples de sucesso em "marketing". Segundo o pastor da IURD do Largo do Machado, um bom pipoqueiro instala-se perto do ponto de ônibus às $18 \mathrm{~h}$, quando as pessoas saem do trabalho, e coloca um diferencial no seu produto. Ele pinga um pouco de leite de coco na panela onde cozinha a pipoca doce e, assim, enquanto os clientes vão se aproximando, ela vai sendo preparada fresquinha, exalando um perfume irresistível. De acordo com este pastor, não há "concorrente para essa pipoca".

Quando se colocam em contraste com antigos amigos, parentes ou vizinhos, meus informantes privilegiam a razão como eixo da sua percepção de si. A conversão e a manutenção da conduta exigida do homem evangélico, os cálculos necessários à condução de sua vida econômica, além da nãosujeição à ausência - de fato - da igualdade de oportunidades prescrita no Direito e a autoconfiança ilustram suas narrativas do eu.

O estímulo da Igreja ao trabalho empreendedor e a garantia teológica do envolvimento de Deus em seu projeto são aproveitados como capital simbólico da masculinidade e os encorajam a enfrentar riscos e a converter 
a precariedade de suas circunstâncias sociais em "perseverança" e "vitória". O encontro espiritual (Durkheim 1970:303-313) atenua o sentimento de fragilidade provocado por seu isolamento e impele esses homens imbuídos do espírito da acumulação à luta econômica por uma "vida melhor".

Recebido em 07 de setembro de 2009

Aprovado em 03 de março de 2010

Diana Lima é antropóloga, pesquisadora do IESP/UERJ. E-mail: < diana. nogueira@uol.com.br>

\section{Notas}

${ }^{1}$ As atividades da igreja tiveram início em 1977. Em 1990, ela reunia 269 mil pessoas. Em 2000 esse número havia crescido geometricamente, chegando aos 2,1 milhões. Segundo matéria do Grupo de Diários América, publicada no jornal O Globo no dia 1 de fevereiro de 2009, hoje a Igreja Universal tem "quase 8 milhões de fiéis" no país. A matéria não fornecia a fonte desta informação, mas creio que ela, pelo menos, indica uma ordem de grandeza.

${ }^{2}$ Em língua inglesa, ver "If redemption fails, you can still use the free bathroom". The Economist, UK, Jan. 3, 2008. No Brasil, a Igreja Universal em particular assim como outras defensoras da teologia da prosperidade são objeto frequente de notícias depreciativas. Neste momento - agosto de 2009 - mais uma vez as finanças da igreja animam inúmeras páginas em jornais importantes, como O Globo e a Folha de São Paulo.

${ }^{3}$ Não é tarefa simples localizar a igreja no panorama da política partidária brasileira. É verdade que o bispo Marcelo Crivela é senador do PRB, mas não apenas seus políticos estão espalhados por diferentes partidos, como as duas candidaturas do presidente Lula, do Partido dos Trabalhadores, tiveram o seu apoio.

${ }^{4}$ Essas mesmas trajetórias de vida já suscitaram uma primeira discussão (Lima 2008a).

${ }^{5}$ Os informantes não têm memória - nem sua e nem registrada - de gerações anteriores às dos avós.

${ }^{6}$ O belíssimo livro de Paulo Fontes (2008) revigora os estudos sobre este tema tão amplamente abordado. 
${ }^{7}$ As pesquisas e as interpretações mostram que as mulheres são maioria também nas religiões afro-brasileiras. De um modo geral, formam 2/3 do universo de adeptos dessas religiões.

${ }^{8}$ Segundo a literatura, as conversões masculinas são muito mais comuns entre homens mais velhos do que os meus informantes. Na maturidade, os apelos do mundo se tornariam menos irresistíveis, facilitando a conversão.

${ }^{9}$ Existe uma diferença muito grande entre o público das catedrais e o das igrejas de bairro. Não custa lembrar que essa diferença não é específica da IURD. Em todas as religiões, as catedrais são frequentadas em momentos especiais por visitantes eventuais, enquanto nas igrejas locais formam-se pequenos grupos. Os estudos sobre a Igreja Universal são ainda escassos. Entre eles, muito poucos tiveram como base empírica a experiência de fé dos membros vinculados a igrejas pequenas.

${ }^{10}$ Entre as mulheres esse movimento é mais forte, o que, em si, renderia outra análise.

${ }^{11}$ O tráfico de drogas agrava-se muito na década de 1990, ampliando sua presença violenta no Rio de Janeiro e sua capacidade de recrutamento entre rapazes pobres (cf. Zaluar 2004; cf. Machado da Silva 2008). Zaluar (2004:365-396) traz uma elaboração refinada sobre a nada simples e nada imediata relação entre violência, pobreza e masculinidade.

${ }^{12}$ Desde a década de 1990, a intensificada criminalidade violenta na cidade tem deixado a "gente de bem" indignada - além de assustada com a vulnerabilidade à violência criminosa, bem como à policial, nas favelas - e a marcação do contraste entre a sua identidade de trabalhadores e os traficantes ganha estatuto de questão de honra.

${ }^{13} \mathrm{Na}$ rede social por onde andei, no interior da qual todas as mulheres são mais escolarizadas do que os homens, há duas formas de divisão do trabalho entre os gêneros: 1. mulheres que pararam de trabalhar porque, é o que dizem, o marido pode assumir o sustento da família, 2. mulheres que trabalham com seus maridos, mas em um ritmo esporádico, como se fosse um passatempo nobre, e sempre em relação de subalternidade. Uma das mulheres faz graduação em administração, porém é seu marido, Edson, que não tem o ensino fundamental completo, quem toma as decisões na sua empresa de vendas. Isto jamais foi questionado por ela ao longo da minha permanência em seu escritório ou do convívio como um todo entre eles. Nesse período, Edson descobriu que estava inadimplente com o Estado (segundo outro informante, Edson não recolhia impostos até então porque desconhecia a existência de impostos) e Zilanda não foi consultada para a resolução do "problema". Seus estudos em administração não a credenciam à participação no quadro "executivo" da empresa do marido. E, de sua parte, ela não apenas não se envolveu no "problema" como não me pareceu contrariada com isto.

${ }^{14}$ Semanalmente, durante os cultos de segunda-feira, sempre dedicados à prosperidade material, o pastor analisa uma parábola contendo uma versão simplificada 
de um caso conhecido de sucesso empresarial, que remete os fiéis à força interna e à crença que cada cristão deve ter em si mesmo. Além de estudarem um breve texto, eles mimetizam o sentimento da vitória através da entoação de hinos. O uso da parábola e dos testemunhos de outros fiéis bem-sucedidos remete a pesquisadora intrigada aos exempla medievais...

${ }^{15}$ A tradição ética conhecida como doutrina dos "Dois caminhos" tem um largo precedente em trechos bíblicos. Para verificar as fontes gregas da doutrina, ver Xenophontes Memorabilia 2.1, 21ff; Hesíodo Work and Days; Pinax de Cebes em Scripta Minora 1, 140f. Para ver como aparece nos primeiros tempos da igreja católica, ver Barnabás 18-20, Constituições Apostólicas 7:1, Clemente de Alexandria, Stromateis, 5:5. Ver também fontes rabínicas: Midrash Tehillim e Midrash Aggadah Jaeger (1961:8-9) também vale ser consultado.

${ }^{16}$ A batalha espiritual é um tema rico. No interior desse debate, Cecília Loreto Mariz (1999:33-48) é imprescindível.

${ }^{17}$ O pagamento do dízimo e de ofertas não é a única forma de expressão do comprometimento ético do fiel com a Igreja e, acima de tudo, com Deus. A IURD enfatiza a assiduidade do comparecimento à igreja, realiza "consagrações", "batismos", "purificações", "propósitos" e constantemente reforça a importância de uma vida condizente com aquilo que seria a vida de uma pessoa que se considera "de Deus".

\section{Referências bibliográficas}

ALMEIDA, Miguel Vale de Almeida. 1995. Senhores de si. Uma interpretação antropológica da masculinidade. Lisboa: Fim de Século Edições LDA.

ARCHETTI, Eduardo P. 2003. Masculinidades. Fútbol, tango y pólo en la Argentina. Buenos Aires: Editorial Antropofagia.

2007. "Estilos de juegos y virtudes masculinas en el fútbol argentino". In: M. Melhuus \& K. A. Stolen (orgs.), Machos, putas, santas. El poder imaginário de gênero em América Latina. Buenos Aires: Editorial Antro. pp. 43-67.

BIRMAN, Patrícia et alli. 1997. O mal à brasileira. Rio de Janeiro: EdUerj.
BIRMAN, Patrícia \& LEITE, Márcia. 2000. "Whatever happened to what used to be the largest Catholic Country in the World?". Daedalus, 129(2):271-290.

BORGES, Dain. 1993. "'Puffu, ugley, slothful, and inert': degeneration in brazilian social thought". Journal of Latin American Studies, 25(2):235-256.

BRUSCO, Elizabeth. 1993. "The reformation of machismo: asceticism and masculinity among colombian evangelicals". In: V. Garrard-Burnett \& D. Stoll (orgs.), Rethinking protestantism in Latin America. Philadelphia: Temple University Press. pp. 143-158. BURDICK, John. 1993a. Looking for God in 
Brazil: the progressive catholic church in urban Brazil's religious arena. Berkeley: University of California Press.

CARDOSO, Adalberto. 2008. "Transição da escola para o trabalho no Brasil: persistência da desigualdade e frustração de expectativas". Dados. Revista de Ciências Sociais, 51(3):569-616.

CARVALHO, José Murilo. 1987. Os bestializados: o Rio de Janeiro e a República que não foi. São Paulo: Companhia das Letras.

CHALHOUB, Sidnei. 2001. Trabalho, lare botequim. O cotidiano dos trabalhadores no Rio de Janeiro da Belle Époque. Campinas: Editora Unicamp.

CORNWALL, Andrea \& LINDISFARNE, Nancy. 1994. Dislocating masculinity: comparative ethnographies. New York: Routledge.

CORRÊA, Mariza. 1994. "Repensando a família patriarcal brasileira". In: A. Arantes et alli (orgs.), Colcha de retalhos: estudos sobre a família no Brasil. Campinas: Editora Unicamp. pp.13-38.

CUCCHIARI, Salvatore. 1990. "Between shame and santification". American Ethnologist, 17(4):607-707.

DECCA, Maria Auxiliadora Guzzo. 1987. A Vida fora das fábricas: cotidiano operário em São Paulo: 1880-1945. São Paulo: Difel.

DUARTE, Luiz Fernando Dias. 1986. As redes do suor. A reprodução social dos trabalhadores da pesca em Jurujuba. Niterói: Eduff.

. 1999. Da vida nervosa nas classes trabalhadoras urbanas. Rio de Janeiro: Jorge Zahar Editor/CNPq . 2005. "Ethos privado e justificação religiosa. Negociações da reprodução na sociedade brasileira". In: M. L. Heilborn et alli (eds.), Sexualidade, família e ethos religioso. Rio de Janeiro: Garamond Universitária. pp. 137-176.

DUMONT, Louis. 1977. Homo aequalis I. Genèse et épanoissement de l'idéo- logie économique. Paris: Éditions Gallimard.

DURKHEIM, Emile. 1970. "L'avenir de la religion". In: La science social e l'action. Paris: PUF. pp. 305-313.

FAORO, Raimundo. 1975. Os donos do poder: formação do patronato político brasileiro. São Paulo: Editora Globo.

FAUSTO, Bóris. 1977. Trabalho urbano e conflito social (1890-1920). Rio de Janeiro: DIFEL.

FERNANDES, Florestan. 2006 [1976]. A revolução burguesa no Brasil. Ensaio de interpretação sociológica. São Paulo: Editora Globo.

FONSECA, Alexandre Brasil. 2000. "Nova Era Evangélica, Confissão Positiva e o Crescimento dos Sem-Religião". NUMEN, Revista de Estudos e Pesquisa da Religião, (3)2: 63-90.

FONTES, Paulo. 2008. Um Nordeste em São Paulo. Trabalhadores migrantes em São Miguel paulista (1945-66). Rio de Janeiro: Editora.

FOUCAULT, Michel. 1966. Les mots et les choses. Une archeologie des sciences humaines. Paris: Éditions Gallimard.

FRANCO, Maria Sílvia Carvalho. 1976 Homens livres na ordem escravocrata. São Paulo: Ática.

GIUMBELLI, Emerson. 2001. "A vontade de saber: terminologias e classificações sobre o protestantismo brasileiro". Religião e Sociedade, 21(1):87-120.

GUTMANN, Matthew. C. 1996. The meaning of macho: being a man in Mexico City. Berkley: University of California Press.

HEFNER, Robert William. 1993. "World building and the rationality of conversion". In: Conversion to Christianity. Historical and anthropological perspective on a great transformation. Berkeley, L.A.; Oxford: University of California Press. pp. 3-46.

HERZFELD, Michael. 1985. The poetics of manhood. Contest and identity in a 
creatan mountain village. Princeton: Princeton University Press.

HOLANDA, Sergio Buarque de. 1971. Raízes do Brasil. Rio de Janeiro: J. Olympio.

JAEGER, Werner Wilhelm. 1961. Early Christianity and Geek Paideia. Cambridge: Belknap Press of Harvard University Press.

KOWARIC, Lúcio. 1987. Trabalho e vadiagem. A origem do trabalho livre no Brasil. São Paulo: Brasiliense.

LIMA, Diana. 2007a. "Trabalho, mudança de vida e prosperidade entre fiéis da Igreja Universal do Reino de Deus". Religião e Sociedade, 27(1):132-155. 2007b. "Ethos emergente: as pessoas, as palavras e as coisas". Horizontes Antropológicos, 28:175-202.

2008a. "Prosperidade na década de 1990: etnografia do compromisso de trabalho entre Deus e o fiel da Igreja Universal do Reino de Deus". Dados. Revista de Ciências Sociais, 51(1):7-36.

. 2008b. Sujeitos e objetos do sucesso. Antropologia do Brasil emergente. Rio de Janeiro: Faperj e Garamond.

LOPES, José Sergio Leite. 1978. O vapor do diabo: o trabalho dos operários do açúcar. Rio de Janeiro: Paz e Terra.

MACHADO, Maria das Dores Campos. 1996. Carismáticos e pentecostais: adesão religiosa na esfera familiar. Campinas: Editora Autores Associados/ANPOCS.

MACHADO DA SILVA, Luiz Antônio et alli. 2008. Vida sob cerco. Violência e rotina nas favelas do Rio de Janeiro. Rio de Janeiro: Editora Nova Fronteira.

MAFRA, Clara. 2002. Na posse da palavra - religião, conversão e liberdade pessoal em dois contextos nacionais. Lisboa: Imprensa de Ciências Sociais do Instituto de Ciências Sociais da Universidade de Lisboa.

MARIZ, Cecília L. 1995. "Perspectivas sociológicas sobre o pentecostalismo e o neopentecostalismo". Revista de Cultura Teológica, 3:37-52.

. 1999. "A teologia da batalha espiritual: uma revisão bibliográfica". Revista Brasileira de Informação Bibliográfica em Ciências Sociais, 47(1):33-48.

. \& MACHADO, Maria das Dores C. 1996. "Pentecostalismo e a redefinição do feminino". Religião e Sociedade, 17:141-159.

PRADO, Maria Emília. 2005. Memorial das desigualdades. Os impasses da cidadania no Brasil, 1870/1902. Rio de Janeiro: Editora Revan e Faperj.

PRADO JÚNIOR, Caio. 1953. Formação do Brasil contemporâneo. São Paulo: Brasiliense.

RAGO, Margareth. 1985. Do cabaré ao lar. A utopia da cidade disciplinar: Brasil, 1890-1930. Rio de Janeiro: Paz e Terra.

TAYLOR, Charles. 2007. A secular age. Cambridge, Masachusetts and London, England: The Belknap Press of Harvard University Press.

TEIXEIRA, Faustino \& MENEZES, Renata. 2006. As religióes no Brasil. Continuidades e rupturas. Petrópolis: Editora Vozes.

VEYNE, Paul. 2007. Quand notre monde est devenu chrétien. Paris: Albin Michel. . 1987. Sur l'individu. Paris: Seuil.

WEBER, Max. 2004 [1918-1922]. Economia e sociedade. Brasília: Editora UNB.

WEINSTEIN, Barbara. 1996. For social peace in Brazil: industrialists and the remaking of the working class in São Paulo, 1920-1964. Chapel Hill/London: University of North Carolina Press.

ZALUAR, Alba. 1985. A máquina e a revolta. As organizaçóes populares e o significado da pobreza. São Paulo: Editora Brasiliense. .2004. Integração perversa: pobreza e tráfico de drogas. Rio de Janeiro: Editora da Fundação Getúlio Vargas. 


\section{Resumo}

O objetivo deste artigo é pensar sobre os processos de racionalização que operam na adesão à mensagem individualista da teologia da prosperidade. Para ampliar a compreensão do carisma desta vertente do cristianismo, são examinados elementos dispostos à subjetivação masculina, tais como aparecem para os integrantes de uma rede masculina de fiéis da Igreja Universal do Reino de Deus. Essa rede é formada por cerca de 20 homens em situação civil variada, com idades entre 18 e 45 anos, que vivem em favelas ou em ladeiras situadas nos limites entre a zona sul e o Centro da cidade do Rio de Janeiro, e têm baixa instrução. Em suas estratégias (privadas e individuais) para o enfrentamento dos dilemas que se lhes colocam e na urgência com que entre eles se impõem os desafios econômicos, reside rico conjunto de indícios para o entendimento da penetração da Igreja Universal nas camadas populares urbanas.

Palavras-chave Deus, Trabalho, Masculinidade, Conversão, Pentecostal.

\section{Abstract}

This article explores the processes of rationalization involved in a person's adherence to the individualist message of prosperity theology. Looking to gain a better understanding of the charisma associated with this version of Christianity, the text examines a number of elements used in the construction of male subjectivities, such as they appear to members of a network of worshippers from the Universal Church of the Kingdom of God. This network is formed by around 20 men, both single and married, aged between 18 and 45 years with low levels of schooling, living in favelas or on hillsides located on the boundary between the south zone and centre of Rio de Janeiro. Their private and individual strategies for dealing with the problems surfacing in their day-to-day lives and the urgency of the economic challenges confronting them contain a rich set of data, providing us with an insight into the reasons behind the Universal Church's penetration of Brazil's urban working classes.

Key words God, Work, Masculinity, Conversion, Pentecostalism. 